\title{
WORK IN THE LIVES OF WOMEN WITH MANY CHILDREN LIVING IN POVERTY IN THE CONTEXT OF REFORMS IN POLAND'S FAMILY POLICY - CONTINUATION OR CHANGE?
}

\begin{abstract}
The article discusses unpaid housework done by women with many children living in poverty, and the women's attitudes towards employment. The empirical basis of the article is in-depth interviews conducted in 2013-2014 and in 2017. The interviewees were poorly educated mothers; they are usually absent from the labour market, take care of at least three children mostly by themselves (also in two-parent families) and manage their privation. Their roles involve taking care of the family, dealing with everyday problems and seeking help. Daily problems and routine make their activities both burdensome and not very satisfying, which encourages them to dream of "running away from home" into a job.

A shift in Poland's family policy (the introduction of the "Family 500+" programme) gave an opportunity to diagnose changes occurring in different areas of the respondents' lives. The article attempts to answer the questions: Have - and if so to what extent - new benefits modified the women's attitudes toward paid employment? Have the benefits affected their declared willingness to enter the labour market or made them resign from paid employment? In a broader perspective, the article attempts to find out whether the programme, which significantly improved the financial situation of poor families, paradoxically constitutes an additional barrier (apart from the lack
\end{abstract}

* Dr; e-mail: I.Kazmierczak-Kaluzna@is.uz.zgora.pl 
of professional qualifications and taking care of children) in the occupational activity of this category of women. Relatively high resources, despite the obvious advantages, seem to weaken the determination of the respondents to take up paid jobs and thus problematise the situation of at least some of them. In the near future, after their children grow up and do not need the mother's care, the women will lose the right to the benefits, which are probably their basic source of income, and will have no retirement rights. Moreover, they may experience a sense of emptiness after losing the role of the full-time mother - the only important role for their identities.

Keywords: large families, motherhood, family roles, poverty, family policy, unpaid housework, paid job, interpretive paradigm

\section{INTRODUCTION}

Work is one of the dominant human activities that constitute the centre of everyday functioning and one of the main elements of individual identity [Phelps 2013]. As an important area of self-identification, it affects self-esteem, builds awareness of being efficient and useful, enables people to meet self-fulfilment needs, and promotes the establishing of interpersonal contacts. Moreover, it is an obvious source of income. In other words, it has a significant impact on the quality and conditions of our existence [Jezior 2005, Marody 2012]. In the contemporary world, a "good" job is considered to be a condition of inclusion - a "ticket to the world of resources" [Dahrendorf 1993]. It gives a chance to participate fully in the mainstream of social functioning. It also sets the boundaries between the world of prosperity, represented by well-employed and wealthy consumers with multiple sources of capital, who have the competence and resources to actively respond to new offers and really choose from them, and the world of the excluded, represented by uneducated, poor and "unnecessary" "consumers with flaws", who are the systemic costs of modernisation processes. The excluded women function outside the labour market or, at most, represent the working poor subclass, not able (or unwilling) to "respond properly" to contemporary challenges [Bauman 1998, 2006].

In the context of work and employment, women who additionally do most of the reproductive labour are in a specific situation. The housework they do is not prestigious, it is underestimated and usually performed free of charge [Titkow, Duch-Krzystoszek, Budrowska 2004]. In the public discourse, household 
duties - according to the traditional gender contract assigned to women - are actually outside the sphere of interest of economists and are more often defined as the ordinary "bustle of everyday life" [Budrowska 2009] rather than "production of the fourth sector" [Cloude, Garett 1997]. "Unpaid women's work as a category of the analysis and description of the functioning of society has - not only in Poland - a very short history" [Titkow, Duch-Krzystoszek, Budrowska 2004:10]. In recent decades, however, as a result of the activities of feminist circles and women's social movements [see: "Wages for Housework" - Federici 2017] and other factors, attempts have been made to determine the relationship between paid work and unpaid work performed in a household. These processes have been facilitated by changes taking place in the structure of households, changes in stereotypes and definitions of gender roles, as well as the progressive processes of the de-familialisation of care [e.g. Wójcicka 2009].

This article discusses the everyday life of one of the categories of the excluded - women with many children (and their families), benefiting from the institutional support of social assistance. The respondents usually function outside the labour market, i.e., as unemployed - they «do not work», and yet often experience a «triple load» [Standing 2014]. Firstly, they «take care of the household», doing most of the housework and taking full-time care of several children. Secondly, they are responsible for caring for elderly, ill or disabled family members. And thirdly, they are under pressure - more or less clearly articulated by the environment - to earn money and participate in the costs of maintaining the household, support partners who possibly work, and reduce the burden on public welfare institutions. Recognising the accuracy of this view on «non-working», though seriously overworked, mothers, the analysis refers to the unpaid work they do in the household for the family, and paid work, which is usually insecure, badly paid and performed under civil law employment contracts or as a grey market job without social insurance. Even more often, it remains only the respondents〉 declared aspiration or dream.

In the literature, the authentic orientation towards employment in the case of mothers experiencing poverty is usually identified as one of the correlates of their subjectivity and resourcefulness. Multifaceted, it is not only the family's financial problems (e.g. their partnerss alcoholism or lack of a partner) that often force women, who are burdened with household duties and responsibility for managing finances in low-income households, to «absorb shocks» by taking on paid employment [Warzywoda-Kruszyńska 1999; Kawczyńska-Butrym 2004, Lister 2007, Kaźmierczak-Kałużna 2012a]. 
The empirical basis for the study is interviews conducted among administratively poor ${ }^{1}$ large families who, in accordance with the Act on Family Benefits [O.J. 2003 No 228 item 2255], are defined as families bringing up three or more children entitled to family benefits. However, in this study, poverty is treated as a multidimensional phenomenon that is not limited to material deprivation. The adopted economic criteria were to help separate a relatively homogeneous research sample. The adopted broad perspective on the definition of poverty, which makes it close to the concept of exclusion, gives an opportunity to highlight the social or political disadvantage of the poor, points to deficits in cultural capital, difficulties in access to education, health care, the labour market and consumption, and also the inability to implement basic human rights and dignity needs [see: Tarkowska 2000; Grotowska-Leder 2002; Palska 2002; Karwacki 2006; Lister 2007; Kaźmierczak-Kałużna 2012a, 2012b]. Most of the above features of multidimensional poverty are reflected in the interviews.

The interviews were conducted in 2013-2014 (59 interviews) and in 2017 (27 interviews) only with mothers who, due to traditional family roles, are usually the main organisers of home life. This regularity is confirmed by numerous studies conducted among the poor [Lewis 1978; Warzywoda-Kruszyńska 1999, 2001; Tarkowska 2000; Kawczyńska-Butrym 2004]. The change in Poland's family policy in 2016, i.e., the introduction of the "Family 500+" programme, made a return to the respondents in 2017 a unique opportunity to capture potential changes in various areas of their lives (also in terms of employment, attitude to work, etc.), including those resulting from the introduction of child benefits ${ }^{2}$.

1 In the first stage of the research, the basic criterion for selecting the sample, apart from the number of children, was statutory poverty. The research covered those entitled to benefits under the Act on Social Assistance [O.J. 2004 No 64 item 593]. This way of defining poverty results from the widespread acceptance among researchers to identify poverty with receiving financial support from the state [Grotowska-Leder 2002]. In the second stage of the research, several families were not entitled to social assistance benefits. Pursuant to the Act, the income criterion entitling someone to acquire benefits was PLN 542 per person who lives alone and PLN 456 per person in the family at the time of the first stage of the project. During the second stage, the threshold was higher and it was PLN 634 and PLN 514, respectively.

2 The „Family 500+” programme launched under the Act on State Aid in Raising Children [O.J. 2016 item 195] consists in the child allowance of 500 zloty for the second and every next child (until they turn 18), regardless of the material status of the family. Parents or caretakers receive the child allowance for the first or only child only if they meet the income criterion described in the act. For many months preceding its introduction and subsequent months after its entry into force, the programme was widely discussed in public debates. The media discourse was deeply polarised [see: Rymsza 2017], both in relation to the pronatalist goals assumed by the government and its social effects, including limiting poverty and minimising its range. 
Recent surveys on household budgets conducted by the Central Statistical Office indicate a general improvement in the financial situation of Polish families, including a gradual reduction of relative poverty (from $15.5 \%$ in 2015 to $13.9 \%$ in 2016) and extreme poverty (from 6.5\% in 2015 to $4.9 \%$ in 2016). A significant decrease in extreme poverty was recorded, especially among the residents of rural areas and small towns, in households with people with disabilities, in families with low-educated fathers, and in large families (16.7\% in $2015-9.9 \%$ in 2016). Factors that co-decide about the improvement include the good economic situation (low unemployment rate, increase in remuneration, etc.) and the introduction of the child allowance [Zasięg ubóstwa... 2017].

In view of the above, one of the main research intentions was a multi-aspect comparison of the situation of families who often experience extreme economic and cultural poverty [Kaźmierczak-Kałużna 2016b], with the situation after the change, when the financial condition of these families objectively improved. What is important is that work-related topics were just some of the many areas discussed in the interviews. They were not central issues, but nevertheless, they often complemented other issues (the family's financial situation, attitudes to education, temporal orientation, etc.), which enabled a more comprehensive understanding of family life images presented by the respondents.

The Labour Force Survey (LFS) carried out by the Central Statistical Office also indicates a decline in women's economic activity in the last quarter of 2017 [Aktywność ekonomiczna... 2018], which in the public discourse is sometimes identified as an effect of the government's programme. Therefore, this article attempts to answer the question: Have new benefits that improved the financial situation of families also affected the change of the respondents' attitudes towards paid employment and their readiness to take a job or resign from one (and if so, to what extent)?

This article analyses the respondents' statements on the scope and nature of their household duties, their self-identifications (especially aspirational ones) and opinions on paid employment and its meaning in the life of the individual. Special attention was paid to those parts of the interviews that concerned the "Family 500+" programme.

\section{THEORETICAL AND METHODOLOGICAL INSPIRATIONS}

In both research stages, in-depth interviews were conducted with the women, with elements of narrative interviews, using a list of general instructions. The researchers followed the classical postulates for qualitative research and interpre- 
tive paradigm as closely as possible [Wyka 1993]. During the material collection and its analysis, the emphasis was placed on recognising the competencies of the respondents, respecting their subjectivity and the autonomy of their statements. The researchers avoided dictating their conceptual framework to the respondents, and where their openness and communicativeness allowed for it, they chose not to ask questions, instead, conducting a bilateral conversation, with mutual sharing of thoughts and knowledge.

The participants of the study were residents of villages, small towns and medium-sized voivodeship cities ${ }^{3}$. The size of a town/village where the families live was made an additional criterion (apart from having many children and administrative poverty) when selecting the sample for the first stage of the research. In this way, an attempt was made to reflect demographic trends (the majority of large Polish families reside in rural areas - see: Gospodarstwa domowe i rodziny... 2014: 85-95) and grasp the potential differences in the lifestyle and functioning of urban and rural families. In 2013-2014, 24 interviews were carried out in villages (40\%), 20 interviews in small towns (34\%) and 15 in a medium-sized town $(26 \%)$. In the second stage, the proportions were identical: 11 interviews in villages (41\%), 9 in small towns (33\%), and 7 medium-sized towns (26\%). In 2017, the interviews were conducted in less than half of the previously studied families. This was due to frequent refusals to participate in the study, difficulties in reaching some mothers (they had changed the place of residence, etc.) and applying an additional criterion, which was obtaining benefits from the "Family $500+$ " programme.

In both stages, every effort was made to conduct the interviews in the "natural environment" of the women, preferably in their flats. It was to provide comfort and a sense of security to the respondents and to enable the completion of the interviews with sociological observation. It was achieved in the vast majority of cases. Ten interviews (12\%) took place outside the respondents' home. However, despite the obvious research benefits, conducting the interviews at the respondent's home also brought difficulties. As expected, some conversations were disrupted by the presence of third parties (other household members and people staying in the respondent's home). During the majority of the interviews, the respondents were accompanied by their children, especially the youngest ones (infants and

Due to logistical and - equally important - financial reasons, the research was carried out mainly in the lubuskie voivodeship (50 interviews in the first stage, 24 in the second stage). A dozen or so interviews were conducted with the residents of two neighbouring voivodeships - wielkopolskie voivodeship (6 interviews - stage 1, 2 interviews - stage 2) and dolnośląskie voivodeship (3 interviews - stage 1, 1 intrview - stage 2). 
several-year-olds), almost exclusively looked after by their mothers. The children often distracted their mothers' attention from the interview and wanted the women to take care of them. The women's partners also influenced the course of the study, though less often, by interrupting with their own replies, and completing or correcting the respondents' statements. Their presence was usually read in terms of control, and some participants in the project became embarrassed. Nevertheless, as in every other stage of the research, in this case, the researchers attempted to gain as much information as possible. The interviews conducted in the presence of third parties enabled the researchers to assess (externally) the relationships between family members (between spouses, parents and children, etc.) and describe the unique nature of family communication, etc. The background of the research situations, available through observation, allowed the researchers to enrich the analysis with an additional, objectified dimension.

When designing the study, it was decided that there should be great flexibility in research approaches and to draw theoretical and methodological inspirations from several sources. The issues raised during the interviews referred to the individual experience of the mothers and various aspects of the functioning of their families (including families of origin). Threads related to work, as mentioned above, were among the many discussed in the interviews. The structure of the interview scenarios and the manner in which they were conducted were supposed to capture the specific nature of the mothers' general images of family life, necessary to discover and understand characteristics that are diverse within the studied category and at the same time relatively typical of poor large families, as well as changes in these characteristics. The interviews were intense, which "allows for an in-depth study of a particular topic or experience and constitutes a useful method of conducting interpretative research" [Charmaz 2009: 39]. By using open, non-evaluative questions, the women were encouraged to develop their answers. Simultaneously, a balance between the freedom of narration and its order and focus on topics relevant to the research was kept.

Despite the original assumptions, it was impossible to implement fully the postulate of the direct and almost exclusive relationship between the researcher and the respondents, which would give the opportunity to build a kind of partnership in the interaction for the time of the interviews and their interpretation. This postulate, although considered crucial for the use of the interpretive paradigm [Wyka 1993; Bertaux 1990], is often difficult or impossible to meet. Like many other qualitative studies [Tarkowska 2000; Palska 2002; Oliwa-Ciesielska 2013], in this case, the researcher-respondent relationship was indirect (the interviews were conducted by specially trained people), and conclusions were based on the 
analysis and interpretation of the text - multi-page transcripts of the interviews, comments formed during the analysis, and notes from observations taken by the interviewers.

When preparing and conducting the study, the researchers followed - though not always strictly or exclusively - the guidelines included in the works of classical [Glaser, Strauss 1967] and contemporary authors [Charmaz 2009] on grounded theory. Other important sources of theoretical and methodological inspirations included studies related to the sociology of poverty [e.g. Tarkowska 2000; Tarkowska, Warzywoda-Kruszyńska, Wódz 2003; Palska 2002, Oliwa-Ciesielska 2013], sociology of lifestyles [e.g. Siciński 1978, 2002; Palska 2002] and the works of Daniel Bertaux [Bertaux 1990, 2012; Beratux, Delcroix 2000] on conducting and analysing narrative interviews and autobiographical statements. The directives developed in this way were followed throughout the entire research process.

Firstly, the applied procedures and analyses were assumed to be inductive - the research strategy did not consist in testing detailed hypotheses that were proposed in advance, but in deriving them from the empirical data. Throughout the entire research process, the researchers tried to obtain a large amount of data, avoiding narrowing them and formulating preliminary conclusions that would impose a strictly defined framework for the analyses. The mothers were encouraged to speak freely, and on the basis of their statements, problem threads were constructed and conclusions were drawn.

S e c on d ly, the adopted "internal perspective" of the social reality, assuming openness to the respondents and an attempt to empathise with their situation, required systematic work with the analysed text. To illustrate what the mothers say about their experience and work, how they define work and how they perceive their own family and occupational roles, this text includes numerous quotes from the interviews, which makes it possible to enter the women's (and their families') world and learn more about it. Owing to these illustrations, "narration constantly moves between interpretation and empirical evidence" [Charmaz 2009: 197; see: Palska 2002; Oliwa-Ciesielska 2013].

Thirdly, the interviews were divided into three categories: (1) single interviews, i.e., those conducted only once, in 2013-2014 (in the text they are marked as WB_X, where $\mathrm{X}$ - is the interview number), (2) first interviews carried out in 2013-2014 as one of two (marked in the text as WB_X/1), and (3) second interviews carried out in 2017 (marked in the text as WB_X/2). At the initial stage of the project, a database was prepared to see all the collected material (reading "lengthwise"), as well as individual threads, grouped according to the main research paths (reading "crosswise"). This procedure enabled the researchers to 
conduct thematic analyses (an example of which is this article). In addition, it helped to put the respondents' statements in a broader context, owing to which the conclusions contained many aspects but at the same time were coherent.

F o u r th $1 \mathrm{y}$, in order to avoid simplifications and the temptation to extrapolate general conclusions to the whole population on the basis of the most extreme and at the same time most "effective" cases, a simplified frequency analysis was applied, giving the opportunity to determine the frequency of specific content in the narratives of the respondents. The essence of these efforts was not to conduct a literal, quantitative analysis of the interviews, but to determine the presence of specific threads and hierarchise them.

Fifth $1 y$, the notes taken at every stage turned out to be particularly useful in the process of interpreting data. This procedure, typical of the grounded theory methodology, corresponds well with the method of working with rich qualitative data suggested by Bertaux [1990, 2012] which involves synthesising and deriving conclusions on the basis of comments gathered during analyses. The applied procedures, owing to which the meanings contained in the women's narratives were deciphered as closely to the respondents' intentions as possible, helped the researchers realise Weber's key postulate of humanistic sociology to understand the studied reality.

When presenting the partial research results, an attempt was made to include cases differentiated within the studied population (and at the same time quite typical). This would allow the researchers to formulate more general conclusions in relation to poor large families (here in relation to the work of mothers with many children) and to illustrate the changes in these families which also resulted from the impact of new family policy tools.

\section{THAT'S OBVIOUS: I WASH, COOK, CLEAN... OR A NECESSITY OF EVERYDAY LIFE}

Doing housework is not usually treated as a full-fledged job. First of all, it is unpaid, and its effects are ignored when calculating national budgets. "However, the woman doing housework performs a dozen or so jobs and social roles at the same time: she is a cook, accountant, hygienist, secretary, negotiator, teacher, needlewoman, washerwoman, dressmaker, porter, nutritionist, driver, buyer, nurse, interior decorator, a cleaner, educator, waitress, technician, food engineer, consultant, therapist, and gardener. She needs several hours a day to perform all of these functions" [Środa 2006: 5]. This - in a nutshell - is the everyday life of the mothers included in the research. It gets even more difficult because of the 
bad (or, objectively, not very good in the second stage of the research after the introduction of the "Family 500+" programme) financial situation of the family, as well as problems and deficits in social and cultural capital.

In the majority of the families included in the study, the housework is performed by the mothers. The women are usually solely responsible for "food services" (they prepare breakfasts, lunches, dinners, and packed lunches, and they wash dishes, process food, and do the shopping), "cleaning services" (cleaning) or "clothing services" (washing, ironing, sewing, and clothes repairs). They take care of the children, provide nursing care for younger and disabled children, and control and help the older children with their school work. The characteristic feature of the studied community, which affects the quality of relationships and intra-family relations, as well as the nature of family life images presented by the mothers, is (noticeable in both stages of the research) the absence (or very limited presence) of men as co-hosts, partners and fathers. What is important-the marital status of the respondents is almost irrelevant in this context. Obviously, this situation applies to single mothers, but it is also reflected in two-parent families. In the latter case, the absence of men results from the type of jobs they have (e.g. working overtime, additional sporadic jobs, working away from home), problems they have that hamper or prevent their daily functioning in the family (alcohol problems, severe illness, persistent conflict between partners, etc.) or a combination of these factors. The internalised models of family and gender roles are also essential:

Well, that's obvious, I wash, cook, clean. I walk my youngest daughter to school and I bring her home from school (...). At home, I do housework (...). And my husband works in the commune; he went to be a tractor driver (...). Sometimes he also tries to do some work there after hours, right? (...) to help something and get a few zlotys there and do shopping, doesn't he? (WB_1/1)

It's just everything on my head. (...) You are on your own. (...) And my husband, (...) is addicted to alcohol and he was in rehab. It didn't help. (WB_1/2)

All these duties have been on me and still are. Well, he doesn't have time, simply; he goes out when they are sleeping and comes back when they are already asleep. (WB_25)

I mainly do housework, taking care of the home, the kitchen, the meals, cleaning, work related to the family, and the husband, of course, works on the farm. (WB_9/2)

The range of housework done by the women is illustrated in their statements on their typical day. In this case, the content of the analysed narrations is almost the same. The respondents, often without the support of the partner, are the centre of the home world. Some of them emphasise the monotony, being busy and 
overloaded with repetitive activities, nevertheless they perform their duties with a well-founded sense of life necessity:

I get up at 6.00. I make sandwiches for the kids for school, wake them up, they get up, get dressed, eat breakfast, drink tea, pack their lunch, go to school. And I take care of the little one, wash, clean and cook all the time. And later (...) as there is still some time, I will go out for a walk with the little one. I come home, they come from back school, eat dinner, take a break and then we sit down and do homework. So, it's all the same. (WB_3/1)

I get up in the morning, there's already the laundry, right? My daughter gets ready for school, I get the kids ready for kindergarten, I go shopping, come back, make lunch, clean (...). Then the kids come home, so I go with them to the playground, I come back, make dinner, I bath them, they go to bed, and that's (...) my whole day. (WB_16)

Typical [day]? The same as every mother, every woman. I also get up, breakfast, cleaning, washing, cooking lunch, need to stay with the kids, talk a bit. In the evening, dinner again. Just a typical day. (WB_10/2)

In a wider perspective, the mothers do not just do most of the housework, but they actually manage the household, acting as household managers. Their jobs also include balancing the budget, seeking help, contacting institutions (school, social welfare centre, aid organisations, etc.) and trying to plan the family's future. Especially in the first stage of the research, in the conditions of much greater material deprivation of families, the respondents revealed clear features of the contemporary Polish Mother syndrome [see: Lesińska-Sawicka 2008]"

Well, everything is on my head and all the time I think how I can do it (...), I try to get out of this whole situation, just to somehow get out of it and just to keep this money at home, but for now, it's hard for me. (WB_14)

I'm the mother, I'm the father. That's for sure. (WB_40/1)

4 The model of the heroic Polish Mother, who was able to face any difficulties posed by reality, emerged when Poland lost its independence and statehood. The model is still alive in Polish culture and literature. The core of the concept and basic role of the mother has the value of universality and seems to have remained unchanged for centuries, although modern mothers differ in the implementation of their maternal roles from those implemented by women several decades or several hundred years ago. The responsibility for keeping the national tradition, faith or purity of the Polish language has been replaced by more usual tasks. Today, contemporary Polish Mothers, sometimes out of necessity, often alone and deprived of help from partners or husbands, play the roles stereotypically attributed to men and fathers, combine household and parental duties with paid employment, are real "heads of families", and make all decisions. Therefore, they are fully responsible for the functioning of the home and family [see: Titkow 2007]. 
In the public discourse, the unpaid work of women, usually burdensome and not prestigious, is more and more frequently identified as a kind of activity that - due to its importance - requires regulation, even taking into account the principles of distributive justice. However, none of the respondents signals even minimal expectations towards any forms of gratification for the work they do. Despite the amount of housework they do, the mothers do not expect payment, they do not mention their pensions (which finds some justification in their specific, temporal presentist orientation), and relatively rarely demand unequivocally greater involvement directly from their partners. They treat looking after the household and children as a woman's natural duty [see: Titkow, Duch-Krzystoszek, Budrowska 2004], an area of activity almost exclusively belonging to the mother, resulting from her role. They limit the role of the man to earning money:

I always say: I bring up the kids and make decisions. My husband has to earn this money so that I have enough to live on. (WB_10/1)

Some do not believe that the partner can do anything useful in the household:

What can he do? Well, he won't do much, he will sometimes help with the homework or send them to bed. (WB_17/1)

Others unequivocally emphasise that household duties are simply not the domain of men:

Well, I try not to burden him with it. (...) I can help him on the farm sometimes, but usually, usually do wife's, things. (WB_9/2)

Mostly, I take care of everything at home (...). My husband-no. My husband works, my husband works in the forest and has a hard job, because when he has to carry that saw on his back for the whole eight hours (...) he will have had enough, no. But if I sometimes need something, I don't really have to tell him: Listen, we need to do this and I can't do it myself. He will be happy to help me there (...), but mostly I struggle with everything by myself. (WB_10/2)

The lack of this type of expectations results from the conviction about the categorical division of duties into typically female and male ones ${ }^{5}$. It is also an element of the habitus of the respondents, i.e., their "socially established nature". Habitus, as a system of internalised attitudes and dispositions, mental patterns

5 Patterns of role division, like fertility patterns and disadvantaged socio-economic status, seem to be inherited for the majority of the respondents. In the women's families of origin, it was mothers who took care of the household and children almost exclusively (sometimes they also had a job). The role of fathers was limited to earning money. At home, they were sometimes responsible for doing harder work [Kaźmierczak-Kałużna 2016a, 2016b]. 
implanted in the individual in the processes of primary socialisation, is a kind of adopted "game rules", responsible for the habits, everyday behaviour and relationships between the genders [Bourdieu, Passeron 1990].

In the majority of the analysed narratives, the men are a kind of home background, and their role is reduced to the instrumentally defined function of the income provider, not a husband, life partner or someone special. These types of statements, more often present in the first stage of the research, correspond well with the culture of poverty concept by Oscar Lewis [1978]. One of its main determinants is women's approval of a patriarchal pattern of relationship. According to it, despite the man's incomparably smaller involvement in household jobs, he usually has a special position in the family and special treatment. He is often the only decision-maker, especially in financial matters.

However, some of the respondents emphasise that their husbands participate as much as possible in housework and are encouraged (or forced) to engage in family life. Yet, this usually occurs in families in which women have a job or health problems:

My D. is a good father, even very good, a dear daddy. He always hugs [our daughters], kisses them, [lets them sit] on his lap. (...) He cooks, bakes, does everything. (...) Everything. He has time to come from work, cook dinner, do everything. But my girl friends say that there are no such husbands. (...) But it's true for me. (WB_54/2) Yeah, he's got them, he's got [duties at home]. Recently he has been, so to speak forced to help more, as I have been failing in health (...). Well, you know, coal, stuff like that, it's his lot. With $N$. [disabled daughter] a bath, when you have to put her to the bathtub, take her out, it's unfortunately my husband, because he is a big guy, well, he does it, it's his duty. Sometimes he washes the dishes (...). Mostly he drives to the shops, he does shopping (...), it's on him. Taking the little one to school, it is his duty to put her into the car and drive. (...) He must be involved. (WB_6/2)

In the second stage of the research, some mothers pointed to the transformation of their own attitude towards the partner and his role as a husband and father. For example, some of them report noticeably greater independence, declaratively accepted by the men. They are able to decide independently or truly co-decide in many areas of family life. The analysis of all the interviews leads to the conclusion that this results from, among others, the improvement of the financial situation of the families and the fact that the mothers are the main holders of funds received under the "Family 500+" programme. For the first time, some of them hold money other than the husband's wages (insecure and/or almost exclusively available to him) or small, thus quickly spent, social assistance benefits. The mothers are now in possession of money for longer periods of time, which expands the area 
of their emancipation. The money gives them a sense of greater independence, financial freedom and allows them - at least some of them - to plan expenses and manage the family budget rationally. With a better financial situation, the women find it easier to fulfil their roles - not only to manage the household with larger resources, but also to do everyday chores. Some of the women have spent the programme money on their houses/flats - they mention some renovations, arranged bathrooms (often the first one in their family), new furniture and - what is important in this context - the purchase of household appliances that make their housework easier.

The majority of the respondents are aware that they are the ones who are responsible for the current and future fate of the family. This awareness is usually accompanied by a well-founded sense of duty, resulting from accepted patterns of gender and family roles. The "Family 500+" programme has significantly improved the financial condition of the families. In some cases, this improvement has been significant ${ }^{6}$. However, if one looks at the whole researched population (quite homogeneous in many respects) - including the scope and nature of housework performed by the mothers - the "Family 500+" programme has not radically changed it. A significant part of the participants in 2013-2014 functioned in difficult conditions not only because of material deprivation. Economic deprivation was often correlated with other problems. The most noticeable problems that affected the conditions and quality of life included housing problems (extremely substandard houses/flats, lack of basic utilities and equipment, densification, etc.), health problems (especially children's disabilities) and family problems (disturbed family relationships, conflicts, alcoholism, domestic violence, feelings of loneliness, etc.). The 2017 interviews reveal that these problems have remained in the majority of the families and invariably they have remained the problems of the women, who are almost exclusively responsible for coping/dealing with them. Thus, despite their better financial situation, the respondents are still burdened with household chores (which have not been reduced), permanent stress for many of them and expressed by some (though less often) a lack of security and perspectives for a genuine, permanent change (fear of whether the benefits will be continued). They still emphasise that they feel lonely, and they often claim "I'm tired", which suggests their poor mental and physical condition.

6 It should be emphasised that this improvement does not always and exclusively result from the state benefits. In some families, other factors also have a significant impact-older children have grown up and got jobs, the woman or her partner found a job or changed it into a better-paid one, as well as personal and cultural resources of the respondents - resourcefulness, efficacy, a sense of control over their own lives, etc. 


\section{I'D LOVE TO GO TO WORK BUT... OR DECLARED ASPIRATIONS AND REALITY}

The majority of the surveyed women are low or very low educated. They have no professional qualifications, and they function outside the labour market. In the first stage of the research, 40 women $(68 \%)$ had only vocational or lower education (18 of them (30\%) had finished only primary school). The remaining ones declared they had finished secondary school, though not all of them had obtained their school leaving certificate. Eight mothers $(13 \%)$ had graduated from post-secondary schools (one had attended a local college). Before the second stage of the research was started, none of the women had received higher qualifications.

Taking into account the low qualifications of the majority of the women and the high number of children, it is not surprising that only fifteen mothers $(25 \%)$ declared they had paid jobs at the time of the first stage of the research. Six of them only "made a little money" in the grey economy, two of them did short-term intervention work, and one was on maternity leave. In other words, only six women $(10 \%)$ had full-time, legal jobs. Three participants of the study received sickness benefits, and eight received nursing benefits for unemployed parents of disabled children. In 2017, five participants (18\%) were employed. Only in a few cases had the status of the women in the labour market changed - three of them, previously unemployed, had found jobs, while three others, who had previously been employed, were outside the labour market in the second research stage. The group of 6 mothers bringing up children with disabilities and receiving nursing benefits remained unchanged.

Some of the respondents have never been employed due to their very early motherhood. Those who once worked usually resigned immediately after getting pregnant or giving birth to the first child:

I worked as a young girl (...), and later got pregnant with my first daughter and I did not work anymore. (WB_3/1)

(...) I worked for a year or so, not longer. I took care of the kids all the time. (WB_8) I have not worked since my older daughter was born, that's since 1992. (WB_9/1) 'Cause I had no time to work. (...) I finished school and had a baby straight after. And I had kids one after the other. Where was I to work? They were all so little. I had no time for work. Only one [husband] who stayed home and I worked like a slave... And I had a drunkard husband. (WB_19/2)

In both stages of the research, most interviews reveal the dilemma that is - in the respondents' view - natural for a woman: children or career. As a rule, the research participants did not decide consciously about their motherhood and did not 
plan to have a lot of children [Kaźmierczak-Kałużna 2017], so they are convinced that destiny determined their lives, both within the family and outside it. When asked about the reasons of their inactivity in the labour market, only a few point to their insufficient qualifications, while the majority claim they cannot have jobs because they need to care for the children. However, they do not mean their duties resulting from having many children, but the mere fact they have children, which they define as an "obstruction" to taking on a job. The women are convinced that although the children make them more active, above all they need maternal care, and this complicates or makes it impossible for them to start work:

I haven't worked for seventeen years. (...) 'Cause I will not leave them alone. How? Go to work for eight hours? In the morning I have to get them ready before 8.00. And even the job, what would the hours be? From 10 am to 8 pm. I'd come home, and nothing is done (...), and I can't leave the little ones alone. (...) The probation officer would come to me - I also have a probation officer, and she'd say: The children are unattended. I told the probation officer that's the reason why I don't wanna go to work. Maybe when they are bigger, older. (WB_19/1)

When I raise them, I can do something for myself in my life, go to work somewhere. (...) Now I have an obstruction. M. is an obstruction with K. for now. I love them very much, but they are an obstruction because I can't leave the kids alone at home. (WB 32/1)

(...) I earned a little from cleaning (...), but all the time it interferes with my childre$n$ 's life, yes. Because once T. got ill and I had to stay. (...) And some problems with $K$. so I had to give up again, yes. Well, for now, we've decided that as long as she is still so little, and she often gets ill so often, she'll stay here with me. And I'll go and find a job later, won't I. (WB_38/2)

By hierarchising their own social roles, the women have a strong primacy of family commitments. Their present lives - in the first research stage and in the second one after the introduction of the "Family 500+" programme - are shaped by activities resulting from their key role of a mother of several children. For most of them, paid employment is a vague future. The family-work dichotomy is particularly visible in their self-identifications. On their basis, it can be concluded that the central value for the respondents is their children, who need to be taken care of and who make it impossible for the women to take on paid jobs. When asked who they are, the respondents in both stages mostly give the same answer:

First of all, I am a mother and probably it will never change. (WB_41/2)

Nevertheless, they declare a positive attitude to employment. Their tentative plans centre around paid employment. Regardless of the difficulty in designing 
their own aspirations, when asked whom they would like to be, they usually say: "a normal, working woman". This type of response appears more often in the first stage of the research, although it is also present in the interviews from 2017, after the introduction of the new family benefits. The analysis of the parts of the interviews that concern earning and employment reveals the women's need to maintain a positive self-image and confirm objectively that they are socially included. Statements suggesting the desire to belong to the category of employed and better-educated people, who are socially non-disadvantaged, non-unemployed and, consequently, non-poor, are indicators of a reluctance to identify themselves with a low social status and their own, often stigmatising, situation:

I would love to go to work, that's my dream (...). I would not have to get so much help from MOPS (the Municipal Social Welfare Centre) anymore, because it is a shame for me, to go there every month and beg. (WB_38/1)

(...) though I love my little ones more than anything, (...) I would like to feel sometimes not like Isaura the slave woman, who stays home all the time, but just like a normal person (...). I'm going to look for a job even now right now. (WB_38/1)

(...) I just wanted to work, be a normal working woman, pursue my professional plans. (WB_41/1)

I would definitely like to finish university. (...) maybe in education, maybe related to health care, and health care work. And then have a job. (WB_9/2)

The women's ideas about the future of the family are in a similar tone. Employment appears in these projections as a condition for a better tomorrow. When referring to the future of the children, the respondents emphasise the importance of the balance between successful family and professional life, and claim that employment, which gives a sense of security and financial stability, should be a starting point for the children to plan their future:

I try to give them good advice (...) first education, certainly not a family. It is above all (...) to support the family. First, you must get an education, a job (...). Don't get into relationships and then live on social welfare benefits. (WB_39)

Employment itself is defined by the respondents as an important area of social functioning. Regardless of their own status in the labour market, they emphasise its value, paying attention to income and the possibility of meeting the family's needs:

Employment (...) is a source of family income. (...) after all, I won't work for free, I get money. And if you work, you have money, you've got everything. (WB_43/1) 
As a rule, however, the respondents stress the psychosocial aspects of employment, perceiving it as a "getaway" from the "home drudgework". In contrast to monotonous and usually unsatisfying household chores, employment is perceived as a different, more attractive life. On the one hand, it would allow them to take a break from their children, forget about family troubles, break the daily boredom - as some respondents say, and on the other, paradoxically, it would contribute to a better organisation of time and family life. The women are aware that it also gives a sense of security, independence and affects self-esteem. It is also an important platform for establishing and maintaining interpersonal contacts and a chance to enter new social networks, which in the lives of the mothers, often "locked in" at home, is particularly important:

Work is support for me; I have a feeling of security, that I am not dependent on anyone. (...) People look differently at someone like that (...). Oh, I'm worthy, I'm proud to have a job, yes, I'm someone. (WB_32/1)

You know what [employment is]? A getaway. Basically. Money of course, but I mean that I'm among people, that work somehow made me relaxed. I'm among people, quite differently, and not like at home. At home, it is so monotonous (...). When I worked, I used to get home so happy. You talked to someone (...). It's different, isn't it? But I stay here at home, and always alone, and it's so depressing. (WB_32/2)

(...) people don't appreciate what work can give them. It's not just doing some activities. It's also, besides that, contact with people. It's just a bit of a mental disconnect from everyday home and family life, right? Everyone at work has their other private life (...). Somewhere, people fulfil their ambitions. (...) work is not only 8 hours of tapping the keyboard, the computer or standing at the assembly line and doing one thing only, you know, there is also a breakfast break, where you sit and joke, where you meet people (...). Because you talk about different things at work (...) work is not only an unpleasant duty, it is also a second life. (WB_6/1)

A comparative analysis of the interviews from 2013-2014 and 2017 indicates that the respondents did not fundamentally change their attitudes to paid work. They remain quite ambivalent. Employment, described as valuable and desirable, is still more often a declared aspiration rather than part of their daily lives. In some interviews, the impact of social pressure - more or less openly exerted on the respondents - is clearly noticeable. The mothers are aware that they are expected at least to think about taking on a job, especially now when some of them are, as they say, accused of "living off their children". As a rule, however, they do not take any concrete steps to enter the labour market. For at least some of them, it seems to be fully rational - the costs of possible employment (costs of 
childcare, commuting, etc.) outweigh its benefits (low wages for those who have no qualifications, employment contracts that do not guarantee social security etc.).

When they were asked in the second stage of the research for an unambiguous answer about whether they thought mothers should go to work, the respondents most often referred to individual needs, organisational skills, family situation, income and the age of children. They also paid attention to the support they could get, not only from their partner/husband, but also from other family members, e.g. grandparents:

If a woman is able to handle it and has the will, then of course. I had four children, I worked and I did school and I think that at that moment I felt happiest. (WB_28/2) (...) it depends on the situation. If she has the help of good parents who will look after her children, who are responsible, who will cook, do the washing, will make sure that the kids do their homework, so why not. If she is strong enough. But in my opinion, a woman should deal with the house, garden, and children. (WB_1/2) (...) until the child is three, it seems to me that a woman should be at home, with the child, because the child needs this mother, the care. And then there are kindergartens, yes. And, a woman should be independent too, I think. She shouldn't depend on another person. (WB_41/2)

Some mothers openly question paid employment among women and the expectations connected with it. In a broader context, this corresponds well with the determinants discussed above, including inherited patterns of family and gender roles. The respondents emphasise their burden with housework and quite categorically stress traditionally understood men's duties in this regard:

(...) it seems to me that she should stay home and take care of the house, and the guy should work. That's my opinion. A woman does not have as much strength or stamina as a guy. (WB_17/2)

Actually, the man should do everything to ensure that everything is all right at home for the woman. The woman will slave away enough round the house. (WB_19/2)

In the context of the changes that have taken place in the attitudes of the respondents to paid employment as an effect of the newly introduced benefits, one issue draws attention. What is characteristic in the second stage of the research, and what was nearly completely absent in the years 2013-2014, is the calculation. In both stages, many of the respondents list the positive aspects of paid work, but this positive attitude is rarely turned into a true readiness to take on a job. In the second stage of the research, however, they not only point to having children as an "obstacle" in taking on a job (typical of the first stage), but they also carefully calculate whether it is financially profitable for them to go to work. They 
are aware that because of their low qualifications, the employment they could possibly take would not be a "proper" job with satisfying earnings and future pension benefits. Therefore, they calculate whether they will really have more money, taking into account the possibility of losing benefits from Social Welfare Centres and the child-raising benefit for the first child. Due to relatively high benefits currently received, paid employment ceases to be a particularly attractive area for obtaining income. Financial assistance from Social Welfare Centres that the majority of the families still receive in various forms, combined with the child-raising benefit, is enough for them to have a satisfying life (in comparison with the situation a few years ago):

(...) actually, well, it does not pay off for some women to work, because, having $500+$, having the family benefit... Going to work, they have little more, and they can stay at home with children, give their time. (...) I heard that girls resign from work as let's say, they earn 700 zlotys, yes, but they have to be at work a lot of the time, they have no time for the kid, so they choose to stay and not work for that seven hundred, yes. (WB_38/2)

The above and similar statements correspond well with the assumptions of the theory of rational choice [see: Lalman, Oppenheimer, Świstak 1994]. The interviewed mothers rationally choose what is best for them (and their families) at the moment and act in their own interest. They make a specific review and evaluation of the available (though few) options and choose the one which they expect will serve their goals best. The main goal - in the opinion of the interviewees - is to take care of their children. As they currently receive satisfactory funds from sources other than employment, taking on low-paid jobs (and leaving the children without proper care when they are at work) seems to be irrational.

\section{CONCLUSION}

Experiencing multidimensional deprivation favours reducing the function of employment and perceiving it in purely instrumental terms - as a tool for gaining the means needed to survive/ live. This is caused by the economic and cultural deficits of the poor as well as the nature of their work. As they have no qualifications, their employment-often as temporary, low-paid, easily-exchangeable workers, whose tasks do not require special training [see: Urbański 2014] - rarely brings financial satisfaction, and even less often fosters a sense of fulfilment. Thus, employment is usually not a developing pleasure. It is rather a burdensome life necessity. And what is worse, these people still live in poverty or privation. This type of employ- 
ment does not ensure financial stability, does not give a sense of security (also in relation to future pension) and does not help to leave the status of the poor.

The participants - mothers with large families, the vast majority of whom are outside the labour market - appear to be a specific category. Unlike the unpaid work which they do at home and which for most of them is something natural and obvious, and yet seriously burdensome and unsatisfactory, paid employment is seen as a positive change - an escape from everyday duties and problems and a second better life [Kaźmierczak-Kałużna 2016a]. In spite of severe financial deficiencies (especially in the first stage of the research), employment is perceived by the respondents as an activity bringing measurable, mainly non-financial benefits.

The interviews - both in the first and the second stage - reveal the women's need to maintain a positive self-image and an objective confirmation that one is socially included. Employment, defined as an important aspect of individual existence, gives this chance. Therefore, some of the project participants aspire to go beyond family life and wish to belong to the category of people with jobs (employees). The role of the mother, performed by some of the respondents with dedication and against difficulties, allows them to positively evaluate themselves in this aspect of their activity, but it is not the final ambition and aspiration for some. It might seem, therefore, that it is only a matter of time before they will really seek jobs so that they could "take a breath" and escape from the home "treadmill". However, the applied temporal perspective and the analyses carried out in the research lead to the conclusion that statements about employment and the readiness to undertake it are more often opinions constructed under the influence of social expectations, pressure and the fear of seeing oneself as a marginalised individual, reduced only to the biologically determined role of the mother, rather than deliberate views, inducing genuine attempts to find a job.

To sum up, among the numerous (often individualised) factors blocking the activity of women in this field, three general issues should be paid attention to. The first is the insufficient qualifications of the majority of the respondents. Their perception of employment as a "rest" and "pleasure", while not being qualified to perform creative activities that give self-fulfilment, does not look promising. This way of thinking about employment, emphasising its non-financial aspects (when the respondents suffer greater or smaller privation), indicates the women's real tiredness (or boredom) with housework. Nevertheless, it is also an indicator of certain cultural deficits among the mothers who have never worked before (or they had worked briefly, without having a big family) and they are not able 
to predict what additional burden is connected with having a job while running a large family with no partner support.

Secondly, despite their fatigue reported in the interviews, the respondents mostly accept their fate. They perceive their own situation in terms of life's necessity resulting from fairly rigidly defined obligations stemming from family and gender roles, which cannot be changed or negotiated. The natural environment of the researched mothers is home and family. Employment and earning is the domain of men. These opinions, though sometimes hidden, emerge from some of the interviews. In this context, the women's statements about job-seeking plans seem to be a self-defence response to social expectations rather than a ready-made plan awaiting implementation.

Thirdly, the "Family 500+" programme, introduced in 2016, seems to slightly weaken the employment aspirations of the mothers. With the noticeable improvement of the financial situation, the lives of the families are better. It is easier for them to balance family budgets and satisfy their needs. Today, these families - included in the consumption market - can use goods and services previously out of their reach. Thus, in the absence of economic necessity, the women naturally calculate and estimate the profits and losses which their employment would involve. As a result of these calculations, the women's chances of getting out of the circle of exclusively domestic activities seem to be objectively reduced.

What is particularly interesting is that some respondents define employment primarily as a guarantee for the future, after the children grow up and the women lose their rights to benefits currently obtained, when a job will not only be a source of income, but will also fill the gap after their parental roles. They will not end up as "nobody" but they will take over other, non-family duties. In this context, in some interviews, the respondents describe other projected activities for their future - especially the role of grandmothers taking care of grandchildren, which will almost naturally replace the role of the mother. Although this will not give the women any income, it can be a new source of identity, protecting them from a sense of social emptiness. In the feminist trend of the literature, this change of roles is interpreted as a specific manifestation of a woman's fate (and not the effect of free choice), resulting from the subordination of women to gender stereotypes which condemn them to a lifetime performance of unpaid care functions in the household [Titkow 2007].

The requirements of the contemporary labour market are high in terms of its participants' knowledge, competencies, skills and qualifications. Constant activity, permanent development and lifelong education are a must for employees 
and those currently outside the labour market. Thus, the situation of the mothers with large families, who - despite changes in family policy - still represent the world of privation, is difficult in many aspects. Paradoxically, this seems to be strengthened by the "Family 500+" programme, which significantly improved the financial situation of families, but in many cases slightly weakened the determination to seek a job. Thus, it may become another factor that constitutes a barrier to implementing their declared plans to find a job.

\section{REFERENCES}

Aktywność ekonomiczna ludności Polski IV kwartat 2017 roku. 2018. Warszawa: GUS.

Bauman Zygmunt. 1998. "Zbędni, niechciani odtrąceni - czyli o biednych w zamożnym świecie". Kultura i Spoleczeństwo 2: 3-18.

Bauman Zygmunt. 2006. Praca, konsumpcjonizm i nowi ubodzy. Kraków: WAM.

Bertaux Daniel. 1990. Funkcje wypowiedzi autobiograficznych. In: Metoda biograficzna w socjologii, J. Włodarek, M. Ziółkowski (eds.), 71-81. Warszawa-Poznań: PWN.

Bertaux Daniel. 2012. Analiza pojedynczych przypadków (au cas par cas). In: Metoda biograficzna w socjologii. Antologia tekstów, K. Kaźmierska (ed.), 309-333. Kraków: Nomos.

Bertaux Daniel, Cathrine Delcroix. 2000. Case histories of families and social processes: Enriching sociology. In: The turn to biographical methods in social science, P. Chamberayne, J. Bornat, T. Wengraf (eds.), 71-89. London-New York: Routledge.

Bourdieu Pierre, Jean-Claude Passeron. 1990. Reprodukcja. Elementy teorii systemu nauczania. Warszawa: PWN.

Budrowska Bogusława. 2009. Krzątactwo codzienności a perspektywa "trzeciej socjologii". In: Kobiety-Feminizm-Demokracja, B. Budrowska (ed.), 70-92. Warszawa: IFiS PAN.

Charmaz Kathy. 2009. Teoria ugruntowana. Praktyczny przewodnik po analizie jakościowej. Warszawa: PWN.

Cloud Kathleen, Nancy Garrett. 1997. “A modest proposal for inclusion of women's household human capital production in analysis of structural transformation". Feminist Economics 3(1): 151-177.

Dahrendorf Ralph. 1993. Nowoczesny konflikt społeczny. Esej o polityce wolności. Warszawa: Czytelnik.

Federici Silvia. 2017. "Kapitał a płeć". Praktyka Teoretyczna 3: 196-212.

Glaser Barney G., Anselm L. Strauss. 1967. The discovery of grounded theory: Strategies for qualitative research, Chicago: Aldine.

Gospodarstwa domowe i rodziny. Charakterystyka demograficzna. Narodowy Spis Powszechny Ludności i Mieszkań 2011. 2014. Warszawa: GUS.

Grotowska-Leder Jolanta. 2002. Fenomen wielkomiejskiej biedy. Od epizodu do underclass. Łódź: Wydawnictwo Uniwersytetu Łódzkiego.

Jezior Jagoda. 2005. Wartość pracy. Studium socjologiczne na podstawie badań w regionie środkowowschodniej Polski, Lublin: Wydawnictwo UMCS.

Karwacki Arkadiusz. 2006. Błędne koło. Reprodukcja kultury podklasy społecznej, Toruń: Wydawnictwo Uniwersytetu Mikołaja Kopernika. 
Kawczyńska-Butrym Zofia. 2004. Kobiety i ich rodziny w osiedlach byłych pegeerów. Raport, Olsztyn: Wydawnictwo Uniwersytetu Warmińsko-Mazurskiego.

Kaźmierczak-Kałużna Izabela. 2012a. Dwa oblicza biedy. Subiektywne i obiektywne aspekty sytuacji życiowej ubogich. Zielona Góra: Oficyna Wydawnicza Uniwersytetu Zielonogórskiego.

Kaźmierczak-Kałużna Izabela. 2012b. "Ubóstwo jako problem społeczny. Kwestie terminologiczne ustalenia empiryczne”. Kultura i Społeczeństwo 1: 147-157.

Kaźmierczak-Kałużna Izabela. 2016a. Domowe menedżerki - praca w opiniach wielodzietnych matek z ubogich rodzin. In: Praca w XXI wieku. Wymiary formalne i nieformalne, E. Kolasińska, J. Róg-Ilnicka, A. Mrozowicki (eds.), 233-265. Gdańsk: Wydawnictwo Naukowe Katedra.

Kaźmierczak-Kałużna Izabela. 2016b. "Ja bym chciała, żeby moje dzieci mieli szczęśliwe dzieciństwo, nie tak, jak ja... Dzieciństwo własne a dzieciństwo własnych dzieci w narracjach wielodzietnych ubogich kobiet”. Opuscula Sociologica 4: 63-79.

Kaźmierczak-Kałużna Izabela. 2017. Wielodzietność - wybór czy konieczność? Perspektywa ubogich matek. In: Rodzina niejedno ma oblicze - refleksja o współczesnej rodzinie, K. Juszczyk Frelkiewicz, G. Libor, A. Górny, A. Zygmunt (eds.), 47-64. Katowice: Wydawnictwo Uniwersytetu Śląskiego.

Lalman David, Joe Oppenheimer, Piotr Świstak. 1994. "Formalna teoria wyboru racjonalnego: kumulatywne nauki polityczne". Studia Socjologiczne 3-4: 13-62.

Lesińska-Sawicka Małgorzata. 2008. Późne macierzyństwo. Studium socjomedyczne. Warszawa: Nomos.

Lewis Oscar. 1978. The culture of poverty In: Anthropological Essays, O. Lewis (ed.), 67-80. New York: Random House.

Lister Ruth. 2007. Bieda. Warszawa: Sic!

Marody Mirosława. 2012. Dynamika postaw wobec pracy. In: Wartości a zmiany. Przemiany postaw Polaków w jednoczacej się Europie, A. Jasińska-Kania (ed.), 63-77. Warszawa: Wydawnictwo Naukowe Scholar.

Oliwa-Ciesielska Monika. 2013. W poszukiwaniu kultury ubóstwa. Poznań: Wydawnictwo Naukowe UAM.

Palska Hanna. 2002. Bieda i dostatek. O nowych stylach życia w Polsce lat dziewięćdziesiątych. Warszawa: IFiS PAN.

Phelps Edmund S. 2013. Ptaca za pracę. Warszawa: Kurhaus.

Rymsza Marek. 2017. "Zrozumieć ten plus". Więź 3: 7-15.

Siciński Andrzej. (ed.). 1978. Styl życia. Przemiany we wspótczesnej Polsce, Warszawa: PWN.

Siciński Andrzej. 2002. Styl życia, kultura, wybór. Szkice. Warszawa: IFiS PAN.

Standing Guy. 2014. Prekariat. Nowa niebezpieczna klasa. Warszawa: PWN.

Środa Magdalena. 2006. Praca domowa kobiet. In: Nieopłacana praca-jak ja traktować, żeby skutecznie tworzyć podstawy opiekuńczego społeczeństwa? 5-6. Łódź: Instytut Spraw Obywatelskich.

Tarkowska Elżbieta, Wielisława Warzywoda-Kruszyńska, Kazimiera Wódz (eds.). 2003. Biedni o sobie i swoim życiu. Katowice-Warszawa: Wydawnictwo Naukowe „Śląsk”.

Tarkowska Elżbieta (ed.). 2000. Zrozumieć biednego. O dawnej i obecnej biedzie w Polsce. Warszawa: Typografika.

Titkow Anna, Danuta Duch-Krzystoszek, Bogusława Budrowska. 2004. Nieodplatna praca kobiet. Mity, realia, perspektywy. Warszawa: IFiS PAN. 
Titkow Anna. 2007. Tożsamość polskich kobiet. Ciagłość, zmiana, konteksty. Warszawa: IFiS PAN.

Urbański Jarosław. 2014. Prekariat i nowa walka klas. Przeobrażenia współczesnej klasy pracowniczej i jej form walki. Warszawa: Instytut Wydawniczy Książka i Prasa.

Ustawa z dnia 11 lutego 2016 r. o pomocy państwa w wychowywaniu dzieci, Dz. U. 2016 poz. 195. Ustawa z dnia 12 marca 2004 r. o pomocy społecznej, Dz. U. 2004 Nr 64 poz. 593 z późn. zm.

Ustawa z dnia 28 listopada 2003 r. o świadczeniach rodzinnych, Dz. U. 2003 Nr 228 poz. 2255 z późn. zm.

Warzywoda-Kruszyńska Wielisława (ed.). 1999. (Żyć) Na marginesie wielkiego miasta. Łódź: Instytut Socjologii Uniwersytetu Łódzkiego.

Warzywoda-Kruszyńska Wielisława (ed.). 2001. Żyć i pracować w enklawach biedy (klimaty łódzkie. Łódź: Instytut Socjologii Uniwersytetu Łódzkiego.

Wóycicka Irena. 2009. Model opieki w Polsce. In: Strukturalne i kulturowe uwarunkowania aktywności zawodowej kobiet w Polsce, I.E. Kotowska (ed.), 99-117. Warszawa: Wydawnictwo Naukowe Scholar.

Wyka Anna. 1993. Badacz społeczny wobec doświadczenia. Warszawa: IFiS PAN.

Zasięg ubóstwa ekonomicznego w Polsce w 2016 roku (na podstawie badania budżetów gospodarstw domowych. 2017. Warszawa: GUS.

Izabela Kaźmierczak-Kałużna

\section{PRACA W ŻYCIU WIELODZIETNYCH KOBIET DOŚWIADCZAJĄCYCH UBÓSTWA W KONTEKŚCIE REFORM POLITYKI RODZINNEJ W POLSCE - KONTYNUACJA CZY ZMIANA?}

Streszczenie

W artykule podjęto problem nieodpłatnej pracy domowej wielodzietnych ubogich kobiet oraz ich stosunku do pracy zarobkowej. Empiryczną podstawą tekstu są wywiady pogłębione prowadzone w latach 2013-2014 i w roku 2017. Rozmówczyniami były słabo wykształcone i z reguły nieobecne na rynku pracy matki, w większości same (także w przypadku rodzin pełnych) sprawują opiekę nad co najmniej trojgiem dzieci i zarządzają domowym niedostatkiem. $\mathrm{W}$ ich rolę wpisane jest szeroko pojmowane dbanie o dom, radzenie sobie z bieżącymi sprawami i zabieganie o pomoc. Codzienne problemy i rutynowe czynności powodują, że wykonywane zajęcia są zarazem obciążające i niesatysfakcjonujące, co sprzyja marzeniom o ,ucieczce od domu” w pracę zarobkową.

Zwrot w polityce prorodzinnej państwa (program „Rodzina 500+”) dał możliwość zdiagnozowania zmian zachodzących w różnych obszarach życia badanych rodzin. W artykule podjęto próbę odpowiedzi na pytanie: Czy - i ewentualnie w jakim zakresie - nowowprowadzone świadczenia zmodyfikowały stosunek kobiet do zarobkowania, czy wpłynęły na deklarowaną chęć wejścia na rynek pracy lub skłoniły do rezygnacji z zatrudnienia? W szerszej perspektywie jest to pytanie o to, czy program, który znacząco poprawił sytuację materialną ubogich rodzin, paradoksalnie nie stanowi dodatkowej (obok braku kwalifikacji zawodowych i konieczności sprawowania opieki nad dziećmi) bariery w aktywizacji zawodowej tej kategorii kobiet. Relatywnie wysokie środki, pomimo oczywistych pożytków, znacząco osłabiają determinację badanych do podejmowania pracy zarobkowej i problematyzują tym samym sytuację przynajmniej części z nich. 
W niedalekiej przyszłości bowiem, po usamodzielnieniu się dzieci, wygaśnięciu funkcji opiekuńczych matki i pozyskiwanych obecnie z tego tytułu świadczeń, prawdopodobnie pozostaną one nie tylko bez podstawowego źródła dochodów, bez emerytury, ale także z poczuciem pustki po utracie jedynej istotnej dla ich tożsamości roli, jaką jest rola pełnoetatowej matki.

Słowa kluczowe: wielodzietność, macierzyństwo, role rodzinne, ubóstwo, polityka prorodzinna, nieodpłatna praca domowa, praca zarobkowa, paradygmat interpretatywny 